\title{
Crop Load Affects Mineral Concentrations and Incidence of Bitter Pit in 'Cox's Orange Pippin' Apple Fruit
}

\author{
I.B. Ferguson and C.B. Watkins \\ Department of Scientific and Industrial Research Fruit \& Trees, Mt. Albert Research Centre. \\ Private Bag, Auckland, New Zealand \\ Additional index words. Malus domestics, calcium, magnesium, potassium, fruit maturity
}

\begin{abstract}
Apple fruit (Malus domestics Borkh. Cv. Cox's Orange Pippin) were harvested in four orchards from trees growing under the same conditions but differing in crop load. Regardless of fruit size, apples from light-cropping trees had lower $\mathrm{Ca}$ and higher $\mathrm{K}$ concentrations and more bitter pit than did fruit from trees with heavy crop loads. The inverse relationship between $\mathrm{Ca}$ concentration in the fruit and the incidence of bitter pit also varied according to crop load and could affect the ability to predict incidence of bitter pit from Ca measurements. Differences in fruit maturity that would influence bitter pit incidence were not associated with crop load. The enhanced susceptibility to storage disorders, such as bitter pit, in fruit of all sizes from light-cropping trees suggests the need to handle fruit from such trees differently for postharvest storage.
\end{abstract}

Light-cropping apple trees tend to bear fruit that are more susceptible to storage disorders such as bitter pit than are fruit from medium- to heavy-cropping trees (Ferguson and Watkins, 1989). The reason for this has been attributed largely to the increased size of fruit growing on light-cropping trees; large fruit are more susceptible to bitter pit since they tend to have lower Ca concentrations (Ferguson and Triggs, 1990; Perring and Jackson, 1975). Most research on the effect of crop load has involved manipulation of the crop by techniques such as fruit thinning and pruning. Thinning has resulted in 'Cox's Orange Pippin' fruit with higher bitter pit incidence (Sharples, 1964, 1968), and while Ca concentrations were the same in thinned and control fruit in these experiments, $\mathrm{K}, \mathrm{P}$, and $\mathrm{Mg}$ were all higher in apples from thinned trees. Little effect of fruit thinning on bitter pit incidence was found in another study with the same cultivar (Van der Boon, 1980b). Summer pruning can also result in production of fruit with less better pit, although the effect is not consistently related to changes in Ca concentration (Marini and Barden, 1982; Perring and Preston, 1974; Van der Boon, 1980b).

A better understanding of the effect of crop load on fruit quality may come from studies on natural variation, rather than from artificial manipulation of the crop. Palmer (1943) found higher bitter pit incidence in fruit from trees with light crops, and Van der Boon (1980a) found that high fruit : leaf ratios (heavy crop) correlated with lower bitter pit incidence. Because fruit size influences mineral concentrations and incidence of storage disorders, studies assessing the influence of crop load should compare fruit of similar sizes. Sharples (1968) found higher bitter pit incidence in fruit from thinned trees within four size classes.

The relationship between $\mathrm{Ca}$, fruit size, and bitter pit maybe affected by crop load (Ferguson and Triggs, 1990; Ferguson and Watkins, 1989). Consequently, the objective of the present study was to assess the effect of crop load on mineral concentration and quality of fruit after storage, particularly bitter pit

Received for publication 5 July 1991. Accepted for publication 2 Jan. 1992. We thank C. Batt. J.H. Bowen. R.L. Cotter. and A. Gunson for their assistance and the New Zealand Apple' and Pear Marketing Board for financial support. The cost of publishing this paper was defrayed in part by the payment of page charges. Under postal regulations, this paper therefore must be hereby marked advertisement solely to indicate this fact. incidence. Results on several apple cultivars suggest that fruit from light-cropping trees tend to mature earlier (Hulme, 1954; Palmer, 1943; Raphael and O'Loughlin, 1964; Sharples, 1964). Since bitter pit incidence is usually higher in early harvested fruit (Raphael and O'Loughlin, 1964; Watkins et al., 1989b), maturity has to be considered in an assessment of the effects of crop load on bitter pit incidence. We have consequently measured, over a range of fruit sizes, the effects of crop load on mineral content of the fruit, bitter pit incidence and storage quality, and on maturity of fruit at harvest.

\section{Materials and Methods}

Four orchards of 'Cox's Orange Pippin' trees were chosen in the Nelson region, South Island, New Zealand. Within each orchard, a block was chosen that had trees growing under the same soil and cultural conditions. In each block, five uniform trees with a heavy crop load (120 to $130 \mathrm{~kg} /$ tree) and five with a light crop load ( 80 to $90 \mathrm{~kg} /$ tree) were chosen. From each tree, fruit covering a range of fruit sizes was picked at the time of commercial harvest (12 Feb. 1990). Fruit were weight-graded by orchard and crop load category into average fruit weights of $190,168,152,138,127$, and $117 \mathrm{~g}$, corresponding to commercial size classes of $100,113,125,138,150$, and 163 (19 $\mathrm{kg}$ box), respectively. Two samples of 10 fruit per size class were taken for mineral analysis using two cortical plugs per fruit from each of 10 fruit (Turner et al., 1977).

At the same harvest time, four fruit averaging $138 \mathrm{~g}$ from each tree were used to assess maturity. From each fruit, $1 \mathrm{ml}$ of internal gas was drawn into a syringe through a hypodermic needle inserted into the core cavity and analyzed for ethylene by gas chromatography (Philips PU4500 fitted with a flame ionization detector; Philips, England). Background color was assessed using a Minolta Chroma Meter II color reflectance meter (Minolta, Tokyo) under CIE illuminant D65 conditions. Two readings were taken from each fruit and the $a^{*}: b^{*}$ ratios were used to describe the changes in color (Hirst et al., 1990). The percentage of surface with blush was assessed visually by a single assessor. Flesh firmness was measured on opposite sides of pared fruit using an Effegi pressure tester (Effegi, Italy) fitted with an 11.1-mm-diameter head. Soluble solids concentration was measured with a refractometer using juice expressed during flesh firmness measurements. The starch pattern index 
was determined by dipping fruit halves for $30 \mathrm{sec}$ in a solution of $1 \mathrm{~g}$ potassium iodide plus $0.25 \mathrm{~g}$ iodine in $100 \mathrm{ml}$ water and rating hydrolysis on a scale of $\mathrm{O}$ (100\% starch) to 7 (no starch).

At harvest within an orchard, fruit from all five trees in each treatment were combined, and a minimum of 50 fruit per size class were stored in air at $3 \mathrm{C}$ for 10 weeks followed by 1 week at ambient temperatures (15 to $18 \mathrm{C}$ ). Background color and flesh firmness were measured on 20 fruit of average harvest weight (138 g). All remaining fruit were used for assessment of internal bitter pit by slicing each fruit transversely at least three times between the calyx and stem ends and recording the presence of lesions.

Analysis of fruit maturity and quality was carried out for both crop loads. across the four orchards. Analysis of mineral concentrations 'and bitter pit was carried out for six fruit weight classes in each crop load across the four orchards. Statistical analysis was performed using a Genstat.5 package, and analysis of variance was carried out on direct or transformed data as indicated.

\section{Results}

For both the incidence of bitter pit and Ca concentration of the fruit, the effects of orchards were highly significant $(P<$ 0.001 ), but no significant orchard $\times$ crop load interactions existed. Thus, the main effect of crop load on $\mathrm{Ca}$ concentration and bitter pit incidence was the same in all four orchards. In fruit from light-cropping trees, $\mathrm{Ca}$ concentrations were always lower and bitter pit incidence always "correspondingly higher (Table 1). This result was not due to fruit size, since the same pattern was found for all sizes (Fig. 1). In any one orchard, substantial differences in bitter pit incidence were found for fruit of the same size from trees with different crop loads. For example, in one orchard, fruit of average weight (117 g) had bitter pit levels of $1 \%$ and $17 \%$ for heavy and light crops, respectively, and for a fruit weight of $168 \mathrm{~g}, 3 \%$ and $29 \%$.

Crop load did not affect $\mathrm{Mg}$ concentration in the fruit (Table 1). There were significant orchard-to-orchard differences in fruit $\mathrm{Mg}$ and a significant orchard $\times$ crop load interaction $(P<$ 0.001 ). No consistent pattern of changing $\mathrm{Mg}$ concentration was associated with crop load. Potassium was significantly higher in the light-crop fruit (Table 1, Fig. 1), and $\mathrm{Ca}: \mathrm{Mg}$ and $\mathrm{Ca}$ : $\mathrm{K}$ ratios were significantly higher in the heavy-crop fruit than in fruit from light-cropping trees. Analysis of mean data from heavy- and light-crop fruit showed that there was a significant decline in Ca concentration $(P=0.12), \mathrm{Ca}: \mathrm{Mg}$ ratio $(P=$ $0.003)$, and $\mathrm{Ca}: \mathrm{K}$ ratio $(P=0.03)$, and an increase in bitter pit incidence $(P \leq 0.001)$ with increasing fruit weight. There were no such relationships with $\mathrm{Mg}$ or $\mathrm{K}$.

Table 1. Bitter pit incidence and mineral concentrations of apple fruit from heavy- and light-cropping trees. Values are the means from four orchards and six size classes.

\begin{tabular}{|c|c|c|c|c|}
\hline Criterion & Heavy crop & Light crop & SED & $P$ \\
\hline Bitter pit $(\%)^{2}$ & $19.1(15.1)$ & $36.1(36.2)$ & 1.3 & $<0.001$ \\
\hline $\mathrm{Ca}(\mathrm{mg} / 100 \mathrm{~g} \mathrm{FW})^{\mathrm{y}}$ & 2.20 & 1.80 & 0.05 & $<0.001$ \\
\hline $\mathrm{Mg}(\mathrm{mg} / 100 \mathrm{~g} \mathrm{FW})$ & 3.43 & 3.44 & 0.05 & 0.75 \\
\hline $\mathrm{K}(\mathrm{mg} / 100 \mathrm{~g} \mathrm{FW})$ & 113.6 & 123.7 & 1.1 & $<0.001$ \\
\hline $\mathrm{Ca}: \mathrm{Mg}$ & 0.65 & 0.53 & 0.03 & $<0.001$ \\
\hline $\mathrm{Ca} \times 10 / \mathrm{K}$ & 0.20 & 0.15 & 0.01 & $<0.001$ \\
\hline
\end{tabular}

${ }^{2}$ Arcsin transformations were used before analysis. Values in parentheses are back-transformed percentage means.

${ }^{\mathrm{y}} \mathrm{FW}=$ fresh weight.

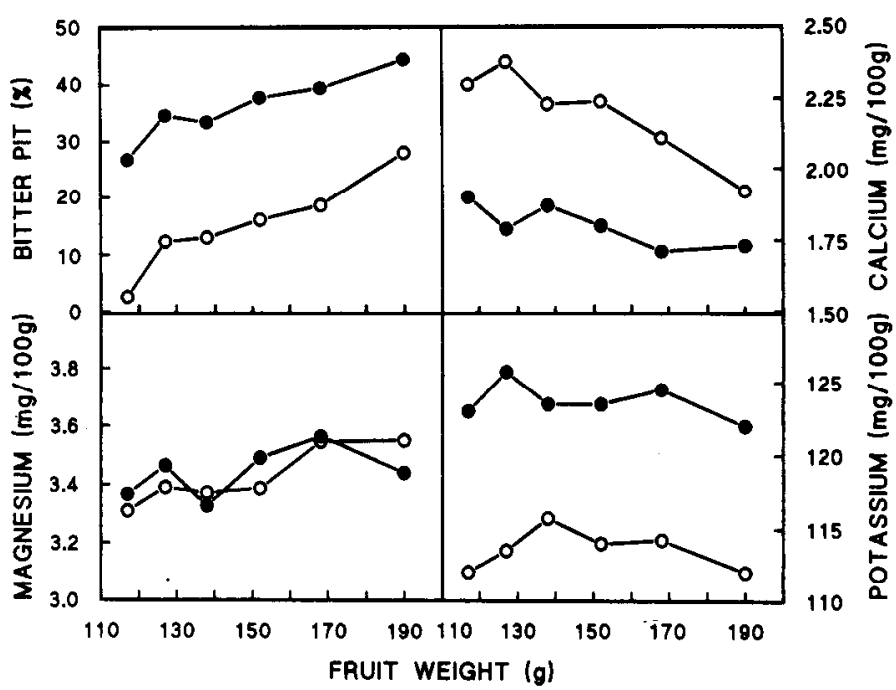

Fig. 1. Bitter pit incidence and $\mathrm{Ca}, \mathrm{Mg}$, and $\mathrm{K}$ concentrations of fruit from heavy-(0) and light-(0) cropping trees. Data are the means from four orchards for each fruit weight. SEDS and $P$ values for the mean data are given in Table 1.

The Ca/bitter pit relationship for all data provided a significant regression $(P<0.001)$, and while the addition of crop load on its own was not significant $(P=0.15)$, the $\mathrm{Ca} \times$ crop load interaction was significant $(P=0.036)$. The relationship appears to be curvilinear, but it could be resolved into two straight lines with different slopes representing the two cropping levels (Fig. 2, top). Including Mg or K improved the relationship with bitter pit, variance being explained by $\mathrm{Ca}(63.3 \%)$ and $\mathrm{Ca}: \mathrm{Mg}$ $(73.3 \%)$ and $\mathrm{Ca}: \mathrm{K}(81.3 \%)$ ratios. With the $\mathrm{Ca}: \mathrm{Mg}$ ratio, there was an effect of crop load $(P=0.056)$ and no mineral $x$ crop load $x$ fruit size interactions, resulting in two parallel straight lines providing the best fit for the data, each pertaining to light or heavy crop load (Fig. 2, bottom). With the Ca : K ratio, there were similar results, except that there was a significant effect of fruit size as well, with one line for each crop load (data not shown).

Highly significant differences $(P<0.001)$ for orchards existed for all fruit maturity factors except the starch pattern index $(P=0.066)$. Only percent blush and internal ethylene concentrations were influenced by crop load, blush being lower in light-cropping trees, and internal ethylene concentrations being higher (Table 2). However, the higher internal ethylene concentrations in fruit from the light-cropping trees than in those from the heavy-cropping trees were due to one orchard having climacteric levels of ethylene in a few individual fruit. In this orchard, internal ethylene concentrations were $11.0 \mu \mathrm{l} \cdot \mathrm{liter}^{-1}$ in the light-crop fruit and $0.1 \mu \mathrm{l} \cdot$ liter in those from heavy-cropping trees.

After storage, fruit from light-crop trees were firmer than fruit from those with heavy crops (Table 2). Although orchard site and fruit size influenced fruit firmness, no consistent trends were apparent. Background color was yellower after storage than at harvest, but it was not affected by crop load (Table 2 ).

\section{Discussion}

Our study indicates that, regardless of fruit size, light-cropping trees produced fruit with lower $\mathrm{Ca}$ and higher $\mathrm{K}$ concentrations and with greater susceptibility to bitter pit. Light-cropping apple trees often bear many large fruit (Sharples, 1968; Van der 

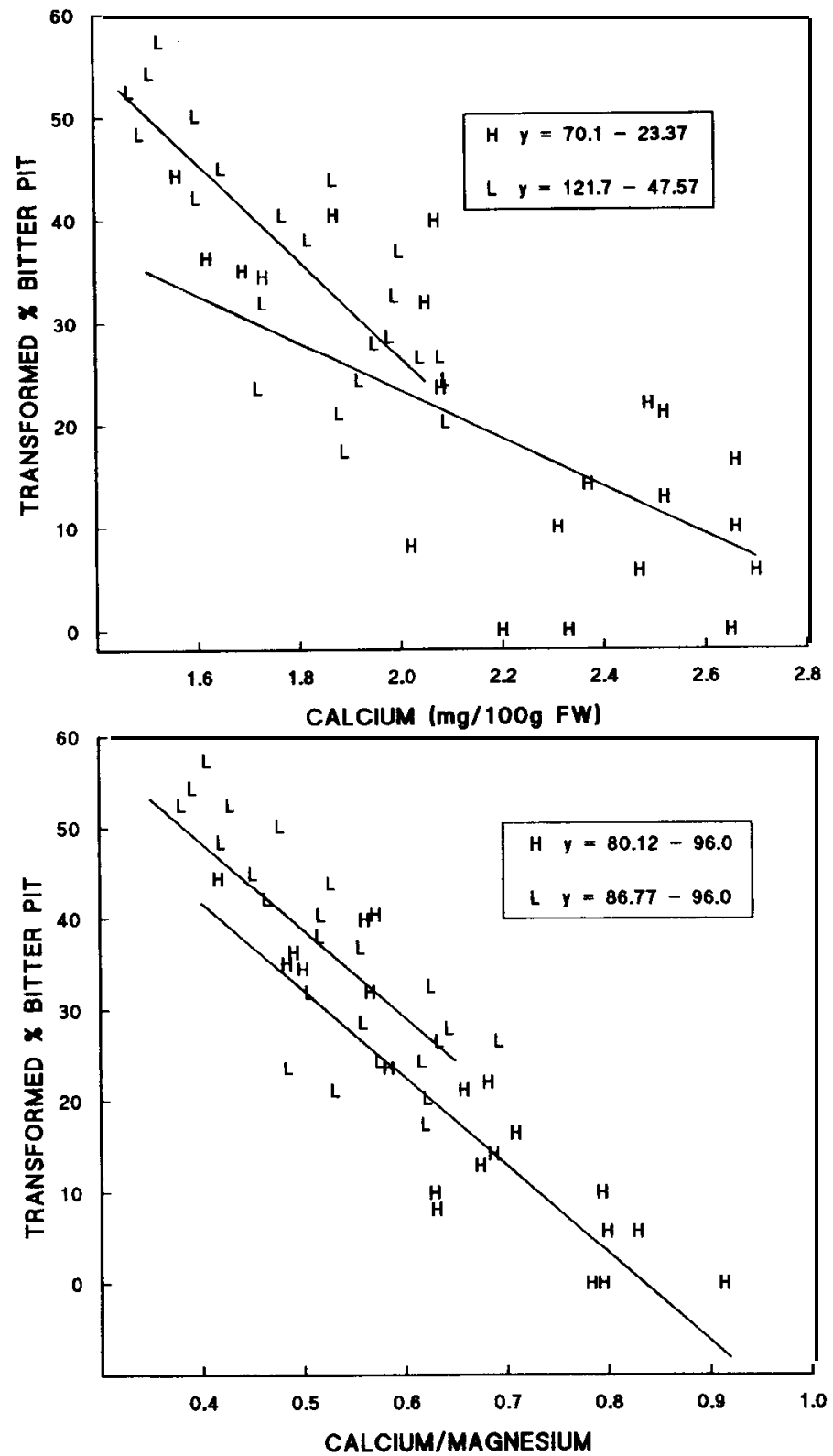

Fig. 2. Relationships between $\overline{\mathrm{Ca}}$ concentration (top) or $\overline{\mathrm{Ca}}: \overline{\mathrm{Mg}}$ ratios (bottom) and bitter pit incidence. Data for heavy-(H) and light-(L) cropping trees are the individual values for six size classes from four orchards. Bitter pit values are arcsin transformations. Lines were fitted as described in Results.

Boon, 1980b). Because large fruit tend to have low Ca concentrations, the crop from light-cropping trees will be more susceptible to Ca-related disorders such as bitter pit. This fruit size/ $\mathrm{Ca}$ relationship has been shown for 'Cox's Orange Pippin' in the present work and in other studies (Ferguson and Triggs, 1990; Perring and Jackson, 1975; Sharples, 1968). An effect of crop load. on mineral concentrations and storage quality of fruit of all sizes has not always been appreciated, although a small effect of crop loading on bitter pit as a result of fruit thinning treatments has been recorded by Sharples (1968).

For unknown reasons, movement of minerals into fruit is affected by crop load independently of the final fruit size. Several features common to light-cropping trees, such as vigorous shoot growth and higher fruit : shoot ratios (Sharples, 1968), undoubtedly affect mineral movement into developing fruit. Fu-
Table 2. Measurements of fruit quality and maturity at harvest and after storage on fruit from heavy- and light-cropping trees. Data are mean values from four orchards.

\begin{tabular}{|c|c|c|c|c|}
\hline Criterion & Heavy crop & Light crop & SED & $P$ \\
\hline \\
\hline $\begin{array}{l}\text { Internal ethylene } \\
\text { concentration } \\
\left(\mu l \cdot \text { liter }^{-1}\right)^{z}\end{array}$ & $0.069(0.1)$ & $0.198(2.8)$ & 0.055 & 0.024 \\
\hline \multicolumn{5}{|l|}{ Background color } \\
\hline$\left(a^{*}: b^{*}\right)$ & -0.455 & -0.448 & 0.004 & 0.084 \\
\hline Blush $(\%)^{z}$ & $34.7(34.5)$ & $17.3(13.3)$ & 2.6 & $<0.001$ \\
\hline Flesh firmness $(\mathrm{N})$ & 78.6 & 79.7 & 0.8 & 0.162 \\
\hline Soluble solids conen (\%) & 10.5 & 10.3 & 0.2 & 0.256 \\
\hline \multicolumn{5}{|l|}{ Starch pattern } \\
\hline index & 1.00 & 1.25 & 0.20 & 0.217 \\
\hline \multicolumn{5}{|l|}{ Background color } \\
\hline$\left(a^{*}: b^{*}\right)$ & -0.250 & -0.245 & 0.003 & 0.112 \\
\hline Flesh firmness $(\mathrm{N})$ & 46.7 & 48.1 & 0.4 & $<0.001$ \\
\hline
\end{tabular}

${ }^{2} \log$ and arcsin transformations were used for ethylene and blush, respectively, before analysis. Values in parentheses are back-transformed means.

ture work should investigate the possible predominance of different fruiting spur types, water relations of the tree, rate of fruit growth, fruit competition within the spur, and the relationship of the developing fruit with spur and bourse leaves on crop load and mineral nutrition. For instance, Sharples (1968) found that light-cropping trees had fewer blossom trusses per branch and less fruit drop over the season than heavy-cropping trees, resulting in more fruit per fruit cluster at the end of the season. Thus, fruit competition and the dynamics of fruit growth may differ according to load. Seed number may also differ in fruit of the same size from different crop loadings, and this may be a factor influencing $\mathrm{Ca}$ concentrations of the fruit (Bramlage et al., 1990). All these factors may influence the supply and movement of $\mathrm{Ca}$ and the other minerals. The opposing effects of crop load on $\mathrm{Ca}$ and $\mathrm{K}$ in the fruit are particularly important, since the effect of low $\mathrm{Ca}$ on fruit quality resulting from light cropping may be exacerbated by concomitant increased levels of $\mathrm{K}$.

The relationship between $\mathrm{Ca}$ and bitter pit appears to differ according to crop load. The absence of a single, straight line relationship for all data (Fig. 2, top) has been noted by others (Ferguson et al., 1979; Van der Boon, 1980b). The resolution into two lines according to crop load is essentially the same as saying that two lines can be obtained according to low and high $\mathrm{Ca}$ concentrations. Differences in the $\mathrm{Ca} / \mathrm{bitter}$ pit relationship associated with $\mathrm{Ca}$ concentration may affect our ability to predict bitter pit from $\mathrm{Ca}$ analysis of fruit within the wide range of $\mathrm{Ca}$ levels expected from different orchards. In practical terms, however, the data for light crops are not very important in that bitter pit incidence was rarely $<15 \%$ and the Ca concentrations rarely $>2.0 \mathrm{mg} / 100 \mathrm{~g}$ fresh weight. Such fruit would not be acceptable for export under current commercial practice in New Zealand, where the above concentration is a minimum level of $\mathrm{Ca}$ in the fruit below which 'Cox's Orange Pippin' fruit cannot be exported. The steeper slope for the light-crop fruit is what might be expected, where Ca concentration is critically low and any small increase might be expected to have a greater effect on bitter pit incidence.

The influence of $\mathrm{Mg}$ and $\mathrm{K}$ maybe important. For instance, the addition of $\mathrm{Mg}$ to the $\mathrm{Ca} / \mathrm{bitter}$ pit relationship provides a more accurate measure of the effect of mineral concentration on bitter pit incidence than $\mathrm{Ca}$ alone (Fig. 2, bottom). There- 
fore, where data do not fit the general pattern of low $\mathrm{Ca} / \mathrm{high}$ bitter pit, a consideration of $\mathrm{Mg}$ and/or $\mathrm{K}$ content of the fruit may provide closer correlations. This relationship can then be used to make more accurate predictions of bitter pit risk from mineral analysis or provide information for the grower, in attempting to improve fruit quality. Although minerals other than $\mathrm{Ca}$ have been incorporated in schemes for predicting a range of storage disorders, few provide better prediction than the use of Ca alone (Ferguson and Watkins, 1989). While crop load affected $\mathrm{K}$ concentration, there was no affect on $\mathrm{Mg}$. However, the effects of these two minerals on bitter pit incidence are expressed through the relationship with $\mathrm{Ca}$. Potassium has been used in conjunction with $\mathrm{Ca}$ in predicting bitter pit incidence (Johnson et al., 1987; Wailer, 1980), and where it is 'high, as in the light-crop fruit, there is likely to be higher bitter pit incidence. Both bitter pit and Ca concentration changed with fruit size for both heavy- and light-crop fruit. The rate of change of $\mathrm{Ca}$ with fruit size appears to be less for light-crop fruit (Fig. 1 ), but this may be due to the smaller range of $\mathrm{Ca}$ concentrations in this set of data. As fruit $\mathrm{Ca}$ concentrations approach the minimum required to sustain fruit growth, the relationship between $\mathrm{Ca}$ and fruit size may disappear. Thus, we might expect that any low-Ca fruit will have a relatively flat regression line of fruit size vs. Ca concentration or bitter pit incidence. Fruit weight has been incorporated, with varying success, into models that predict storage quality and incidence of disorders in several apple cultivars (Autio et al., 1986; Fallahi et al., 1985; Marmo et al., 1985). Accounting for fruit size maybe useful if cropping is heavy. It may be less useful with light-crop fruit where there is a narrower range of low $\mathrm{Ca}$ concentrations and higher disorder incidence.

Fruit maturity is another factor that might be associated with crop load in determining the quality of fruit in storage. Early harvested fruit may be more susceptible to bitter pit (Raphael and O'Loughlin, 1964; Watkins et al., 1989b). Therefore, it was possible that lower bitter pit incidence in fruit from heavycrop trees was due to advanced maturity of this fruit. However, we found little effect of crop load on the maturity factors assessed in our work. Results for internal ethylene concentration suggested that fruit from light-cropping trees were actually more mature than fruit from heavy-cropping trees, but most fruit were preclimacteric, as is usually the case at harvest with this cultivar (Watkins et al., 1989a). Thus, the results with ethylene are inconclusive. The higher percentage blush on fruit from heavycropping trees probably reflects greater exposure of fruit rather than advanced maturity.

In conclusion, light cropping will have a profound effect on the quantity of apple fruit in storage, regardless of fruit size. The crop load should be considered in schemes that predict storage quality and in strategies for maintaining fruit quality in storage.

\section{Literature Cited}

Autio, W. R., W.J. Bramlage, and S.A. Weis. 1986. Predicting poststorage disorders of 'Cox's Orange Pippin' and 'Bramley's Seedling' apples by regression equations. J. Amer. Soc. Hort. Sci. 111:738742 .

Bramlage, W. J., S.A. Weis, and D. W. Greene. 1990. Observations on the relationships among seed number, fruit calcium, and senescent breakdown in apples. HortScience 25:351-353.
Fallahi, E., T.L. Righetti, and D.G. Richardson. 1985. Predictions of quality by preharvest fruit and leaf mineral analyses in 'Starkspur Golden Delicious' apple. J. Amer. Soc. Hort. Sci. 110:524-527.

Ferguson, I.B. and C.M. Triggs. 1990. Sampling factors affecting the use of mineral analysis of apple fruit for the prediction of bitter pit. N.Z. J. Crop Hort. Sci. 18:147-152.

Ferguson, I.B. and C.B. Watkins. 1989. Bitter pit in apple fruit. Hort. Rev. 11:289-355.

Ferguson, I. B., M.S. Reid, and M. Prasad. 1979. Calcium analysis and the prediction of bitter pit in apple fruit. N.Z. J. Agr. Res. 22:485-490.

Hirst, P.M, D.S. Tustin, and I.J. Warrington. 1990. Fruit colour responses of 'Granny Smith' apple to variable light environments, N.Z. J. Crop Hort. Sci. 18:205-214.

Hulme, A.C. 1954. The relation between the rate of respiration of an apple and its content of protein. 11. The value of the relation immediately after picking and at the respiration climacteric. J. Hort. Sci. 29:98-103.

Johnson, D. S., M.J. Marks, and K. Pearson. 1987: Storage quality of Cox's Orange Pippin apples in relation to fruit mineral composition during development. J. Hort. Sci. 62:17-25.

Marini, R.P. and J.A. Barden. 1982. Yield, fruit size, and quality of three cultivars as influenced by summer or dormant pruning. J. Amer. Soc. Hort. Sci. 107:474-479.

Marmo, C. A., W.J. Bramlage, and S.A. Weis. 1985. Effects of fruit maturity, size, and mineral concentrations on predicting the storage life of 'McIntosh' apples. J. Amer. Soc. Hort. Sci. 110:499-502.

Palmer, R.C. 1943. The influence of amount of crop and harvesting maturity on bitter pit in Okanagan-grown Newtown apples. Proc. Amer. Soc. Hort. Sci. 43:63-68.

Perring, M.A. and C.H. Jackson. 1975. The mineral composition of apples. Calcium concentration and bitter pit in relation to mean mass per apple. J. Sci. Food Agr. 26:1493-1502.

Perring, M.A. and A.P. Preston. 1974, The effect of orchard factors on the chemical composition of apples. HI. Some effects of pruning and nitrogen applications on Cox's Orange Pippin fruit. J. Hort. Sci. 49:85-93.

Raphael, T.D. and J,B. O'Loughlin. 1964. Maturity studies on Cox's Orange Pippin. Tasmanian J. Agr. 8:56-58.

Sharples, R.O. 1964. The effects of fruit thinning on the development of Cox's Orange Pippin apples in relation to the incidence of storage disorders. J. Hort. Sci. 39:224-235.

Sharples, R.O. 1968. Fruit-thinning effects on the development and storage quality of Cox's Orange Pippin apple fruits. J. Hort. Sci. 43:359-371.

Turner, N. A., I.B. Ferguson, and R.O. Sharples. 1977. Sampling and analysis for determining the relationship of calcium concentration to bitter pit in apple fruit. N.Z. J. Agr. Res. 20:525-532.

Van der Boon, J. 1980a. Prediction and control of bitter pit in apples. I. Prediction based on mineral leaf composition, cropping levels and summer temperatures. J. Hort. Sci. 55:301-3 12.

Van der Boon, J. 1980b. Prediction and control of bitter pit in apples. II. Control by summer pruning, fruit thinning, delayed harvesting and soil calcium dressings. J. Hort. Sci. 55:313-321.

Watkins, C. B., J.H. Bowen, and V.J. Walker. 1989a. Assessment of ethylene production by apple cultivars in relation to commercial harvest dates. N.Z. J. Crop Hort. Sci. 17:327-331.

Watkins, C. B., E.W. Hewett, C. Bateup, A. Gunson, and C.M. Triggs. 1989b. Relationships between maturity and storage disorders in 'Cox's Orange Pippin' apples as influenced by preharvest calcium and ethephon sprays. N.Z. J. Crop Hort. Sci. 17:283-292.

Wailer, W.M. 1980. Use of apple analysis. p. 383-394. In: D. Atkinson, J.E. Jackson, R.O. Sharples, and W.M. Wailer (eds.). Mineral nutrition of fruit. Butterworths, London. 